Puede citar este artículo como:

Oliver, Clementine. «Murdered in the Tabloids: Billposting and the Destruction of the Duke of Suffolk in 1450». Anales de la Universidad de Alicante. Historia Medieval, N. 19 (2015-2016): 381-402, DOI:10.14198/medieval.2015-2016.19.13

\title{
MURDERED IN THE TABLOIDS: BILLPOSTING AND THE DESTRUCTION OF THE DUKE OF SUFFOLK IN 1450*
}

\author{
Clementine Oliver \\ California State University, Northridge
}

\section{RESUMEN}

Este artículo examina la campaña de comunicación que envolvió el asesinato de la figura política más poderosa de la Inglaterra de mediados del siglo XV, William de la Pole, duque de Suffolk. Primero un héroe de guerra, Suffolk se volvió impopular cuando los ingleses sufrieron una derrota militar en Francia y perdieron Normandía en 1449, un desastre por el que fue particularmente y ampliamente culpado. Fue encausado por el Parlamento, sólo salvado y enviado al exilio por Enrique VI. En su camino al continente su barco fue interceptado por otro llamado Nicholas of the Tower y fue decapitado por los marineros en nombre de la justicia popular. Aquí se examinan los versos y carteles políticos que se pusieron en circulación antes de su asesinato, que satirizaban y arremetían contra el papel del duque en el vacilante gobierno de Enrique VI en las vísperas de la Guerra de las Dos Rosas. La campaña de carteles alentó deliberadamente la caída del duque y su posterior asesinato y, por tanto, Suffolk puede ser considerado la primera gran víctima del periodismo de prototabloides en Inglaterra, indicando la importancia tanto de la publicidad como de la opinión pública en la subsiguiente Guerra de las Dos Rosas.

A preliminary version of this article was presented at the annual meeting of the Medieval Academy of America in Knoxville, Tennessee, 4 April 2013. I thank Courtney M. Booker, Pamela H. Nagami, Curtis F. Oliver, Matthew K. Palmer, Jay Rubenstein, and the anonymous readers for their comments and suggestions. 
Palabras clave: Carteles; Poesía política; Guerra de las Dos Rosas; Duque de Suffolk; Opinión pública.

\section{ABSTRACT}

This essay examines the media campaign surrounding the sensational murder of the most powerful political figure in mid-fifteenth-century England, William de la Pole, duke of Suffolk. Once a great war hero, Suffolk became unpopular when the English suffered military defeat in France and lost Normandy in 1449, a disaster for which Suffolk was singularly blamed by the public at large. He was impeached by parliament only to be saved and sent into exile by King Henry VI. On his journey to the continent his ship was intercepted by another called Nicholas of the Tower, and he was beheaded by the ship's sailors in the name of vigilante justice. This essay considers the political verses or bills put in circulation prior to Suffolk's murder which satirized and lambasted the duke's role in Henry VI's faltering government on the eve of the Wars of the Roses. The billposting campaign deliberately encouraged the duke's downfall and eventual murder, and so Suffolk might be considered the first great victim of proto-tabloid journalism in England, signaling the importance of both publicity and public opinion during the ensuing Wars of the Roses.

Keywords: Billposting; Political Poetry; Wars of the Roses; Duke of Suffolk; Public Opinion.

What follows is a case study of the publicity campaign against the duke of Suffolk that presaged his murder in 1450. While this episode constitutes a very small piece of the history of the Wars of the Roses in England, it may also relate to some of the larger developments observed by John Watts in The Making of Polities: Europe, 1300-1500, specifically in regard to the deployment of media in the fifteenth century. Across Europe at this time political language often «emphasized the common interest of the realm or republic», thereby shaping discourses about government and conceptions of political space which would necessarily come to influence the development of European polities ${ }^{1}$. This case study also follows David Grummitt's analysis of the same period in his recent «short» history of the Wars of the Roses, for 1450 was the moment when the Lancastrian dynasty lost the support of public opinion upon which it had depended for its legitimacy since the deposition of Richard II in $1399^{2}$. Once the genie of the public was out of the bottle,

1 WATTS, J. The Making of Polities: Europe, 1300-1500, Cambridge, 2009, p. 385.

2 GRUMMITT, D., A Short History of the Wars of the Roses, London, 2013. 
it could not be put back again, and though the parallels remain unexplored here, the situation in England has much in common with developments across Europe, where a period of civil wars predated new monarchies. As Watts observes in The Making of Polities, most of the European civil wars had a public dimension. Thus it is to the very public nature of attack on the duke of Suffolk which this essay will now turn.

On 7 May 1453, a chaplain by the name of John Stanes confessed to having assisted his notorious master William Tailboys in a plot to ruin the powerful Lincolnshire magnate Lord Cromwell. William Tailboys, the author of the plot, has been described by the historian Roger Virgoe as a «wealthy, gentle-born gang-leader», and in a common petition from 1449 as a «murderer, manslayer, rioter and continual breaker of your peace», a man who commanded a gang of «slaughterladdes», - a suggestive contemporary term for Tailboys' followers ${ }^{3}$. After having failed in his several attempts to murder Lord Cromwell, in the spring of 1451 Tailboys ordered his servant John Stanes to draw up bills written in rhyme which were posted around London, Kent, and Lincolnshire, and which targeted Cromwell with slanderous accusations. (Unfortunately we do not know what the bills said beyond associating Cromwell with those men thought to be responsible for England's recent losses in France.) In his confession to this plot - and this is where the story becomes interesting - Stanes was quite clear about the inspiration for this libellous campaign, for he knew that «the name of the lord of Suffolk was destroyed be billes made of him and sette upp» ${ }^{4}$.

There exists strong evidence that William Tailboys had enjoyed the protection of the duke of Suffolk, for in 1449 the duke had used his influence to halt criminal proceedings against Tailboys for three murders and several other violent crimes in Lincolnshire ${ }^{5}$. Tailboys' relationship to

3 VIRGOE, R., «William Tailboys and Lord Cromwell: Crime and Politics in Lancastrian England», Bulletin of the John Rylands Library 55 (1973), p. 469, 466; for the description of Tailboys as «murderer, mansleer, riotour», see PROME, parliament of Henry VI, 1449 November, item 56.

4 On verses associating Cromwell with England's losses in France, see VIRGOE, «William Tailboys and Lord Cromwell», p. 470; for Stanes' quotation, see P.R.O., Chancery Miscellanea, C.47/7/8 as transcribed in VIRGOE, p. 477. Cited in WATTS, J., "The Pressure of the Public on Later Medieval Politics», in CLARK, L. and CARPENTER, C., eds., The Fifteenth Century IV, Woodbridge, 2004, p. 171.

5 VIRGOE, «William Tailboys and Lord Cromwell», pp. 464-65; it should be noted that WATTS, J., Henry VI and the Politics of Kingship, Cambridge, 1996, p. 220 offers a different and somewhat apologetic assessment of the relationship between Suffolk and Tailboys; CARPENTER, C., The Wars of the Roses: Politics and the Constitution in England, c. 1437-1509, Cambridge, 1997, p. 109 presents much the same «circumspect» view of Suffolk's alleged protection of William Tailboys. 
Suffolk is significant because it suggests that both Tailboys and his associate John Stanes likely were familiar with the conditions which had led to the duke of Suffolk's downfall in 1450. It is the premise of this essay that the statement made by Stanes in his confession was right on the mark - the aforementioned bills in rhyme posted about the duke played no small part in Suffolk's destruction. As I will discuss below, the duke himself shared this belief. The specific question this essay considers is why such bills in rhyme were particularly effective weapons against someone of Suffolk's stature at this moment in time, the mid-fifteenth century, a moment marked by defeat in France and soon to be followed by rebellion at home. I will begin with the story of the duke's murder as told in the Paston Letters.

In the space of less than a year, William de la Pole, duke of Suffolk, had gone from being the leading and most powerful figure in Henry VI's government, to being impeached by the commons, then exiled by the king's command in an attempt to save him from a traitor's fate, and finally murdered on 2 May 1450. The details of his murder, widely known because they are recorded in a letter from William Lomnor to John Paston, are as follows: On or about 1 May, after Suffolk's small fleet had departed for Calais, they were intercepted by a ship called the Nicholas of the Tower. Suffolk was taken aboard the Nicholas, and there greeted by the ship's master with an ominous, "Welcome traitor» ${ }^{6}$. Roger Virgoe's article on Suffolk's death reveals that when the duke produced his letter of safe conduct from the king, the shipmen replied something to the effect that «they did not know the said king, but they well knew the crown of England, saying that the aforesaid crown was the community of the said realm and that the community of the realm was the crown of the realm ${ }^{7}$. A mock trial was then staged by the crew of the Nicholas, and Suffolk was found guilty of treason. The following day Suffolk was taken off the ship and onto a boat and there beheaded - Lomnor's letter includes the chilling detail that it took half a dozen strokes of a rusty sword. The duke's body was laid on the sands of Dover (there were reports that his head was stuck on a pole beside the body), and his servants were put on shore unharmed.

GAIRDNER, J., ed., The Paston Letters, A.D. 1422-1509, Westminster, 1896, i, p. 125. This remarkable statement has received a good deal of attention from scholars. It is first discussed in VIRGOE, R., "The death of William de la Pole, Duke of Suffolk», Bulletin of the John Rylands Library 47 (1965), p. 499, but see also the indictment printed in the appendix (501) which is the source of the statement made by the crew of the Nicholas (Ancient Indictments of the King's Bench 29 Henry VI: K.B. 9/47, no. 13). For commentary, see WATTS, J., «Ideas, Principles and Politics», in A. J. POLLARD, ed., The Wars of the Roses, London, 1995, pp. 110-11. See also TUCK, A., Crown and Nobility 1272-1461, London, 1986, p. 297; CARPENTER, The Wars of the Roses, p. 114, 161; HARRISS, G., Shaping the Nation: England 1360-1461, Oxford, 2005, p. 255. 
As a young man, Suffolk had spent thirteen years abroad fighting in the war in France, earning steady military advancement and its associated rewards throughout the 1420s. On 11 June 1429, Suffolk surrendered at the siege of Jargeau to a French army led by the twenty-year-old duke of Alençon together with Jeanne d'Arc. Suffolk was made a prisoner, but returned home to England the following year after agreeing to pay a sizable ransom of $£ 20,000$. Decades later, now largely in charge of the peace negotiations between England and France, Suffolk's position weakened as the French king Charles VII outmanoeuvred the English over the course of protracted truce talks ${ }^{8}$. Critics of the policies pursued while Suffolk was ascendant would come to hold him personally responsible for the loss of English territory to the French crown, beginning with Henry VI's promise to surrender Maine in $1445^{\circ}$. As the leading figure in the negotiations, Suffolk had well known that he would be held accountable should the English be perceived as conceding ground for little in return, and he had thrice taken steps to protect himself by declaring publicly and for the record that he acted with the full knowledge and assent of the king and the leading lords ${ }^{10}$. Nevertheless Suffolk's standing as the chief minister in Henry VI's government collapsed at last with the fall of Rouen in October of 1449 and so the loss of Normandy, a loss for which he was roundly blamed by the public at large $e^{11}$.

8 BARKER, J., Conquest: The English Kingdom of France in the Hundred Years War, London, 2009, pp. 338-84, emphasizes the weaker position of the English crown during the truce talks; see also WATTS, Henry VI and the Politics of Kingship, p. 227.

9 On Henry VI's correspondence with Charles VII promising to renounce English sovereignty over Maine, see GRIFFITHS, R. A., The Reign of King Henry VI , Sutton, 2004, p. 495, who sees Margaret's hand at work here. CARPENTER, The Wars of the Roses, p. 101, admits the possibility that Suffolk was behind the surrender. WATTS, Henry VI and the Politics of Kingship, p. 225, n. 86 assumes that the formal promise to hand over Maine was not secret at all, and p. 236 where he suggests that Suffolk carried most of the nobility with him during this period of negotiations. For Gloucester's position and the criticism voiced by soldiers on the front, see GRIFFITHS, p. 494, 500; on tensions with the duke of York see GRIFFITHS, pp. 506-08. For the view that York supported Suffolk's policy, see WATTS, p. 232.

10 The first such declaration was made in 1444, prior to Suffolk's departure for France to negotiate both peace and the king's marriage to Margaret of Anjou. See GRIFFITHS, Reign of King Henry VI, p. 484, n. 13. The second was made before parliament in June 1445, and recorded in the roll of parliament, PROME, parliament of Henry VI, 1445 February, item 2. The third declaration took place on 24 May 1447 in the king's chamber before several lords, and was published under the great seal on 17 June. See GRIFFITHS, p. 499, n. 103.

11 McCUllOCH, D. and JONES, E. D., «Lancastrian Politics, the French War, and the Rise of the Popular Element», Speculum 58, 1 (1983), p. 116. 
Soon thereafter, the duke found himself before parliament to answer charges of impeachment drawn up by the commons, much as his grandfather had in 1386 when Richard II was king - I will return later in this essay to the connection with grandfather Michael de la Pole, earl of Suffolk. The charges drawn up in early 1450 against the duke came in two groups. The first eight articles dealt with the loss of Normandy, accusing Suffolk of conspiring with the French to invade England, of plotting to depose Henry VI and put his own son on the throne, of divulging English military strategy to the enemy for bribes, and of sole responsibility for surrendering the county of Maine to the French crown. The consensus among historians is that these accusations do not hold much water ${ }^{12}$. The second set of eighteen lesser charges dealt with acts of corruption at home, such as embezzling money, enriching himself with lordships which cost the crown revenue, protecting the disreputable William Tailboys, controlling the appointments of sheriffs and so manipulating justice. Historians generally consider these charges more credible, though they were not those which captured the public imagination in the $1450 \mathrm{~s}^{13}$. Suffolk himself was never in doubt as to the impetus behind the attack on him — as he said in parliament he was «subject to odious and horrible langage that renneth through your lande, almoost in every commons mouth $»^{14}$. Suffolk argued that the charges against him had no basis in truth and that he was merely a victim of slander. To his protestation there came an ominous reply of sorts in a satirical political poem attacking one of the duke's associates, bishop William Booth - there it was written that «yt is mych lesse harme to bylle thane to kylle» ${ }^{15}$.

12 See GRIFFITHS, Reign of Henry VI, pp. 678-79; WATTS, Henry VI and the Politics of Kingship, p. 249; GRUMMITT, A Short History of the Wars of the Roses, p. 25.

13 JACOB, E. F., The Fifteenth Century: 1399-1485, Oxford, 1961, p. 498; CARPENTER, The Wars of the Roses, pp. 111-12. See also WATTS, Henry VI and the Politics of Kingship, p. 199, n. 331; HARRISS, G., Shaping the Nation: England 1360-1491, Oxford, 2005, p. 617. GRIFFITHS, Reign of Henry VI, p. 681, regards the second set of charges as insubstantial as the first.

14 PROME, parliament of Henry VI, 1449 November, item 15; SCASE, The Literature of Clamour, p. 121, observes that Suffolk was attempting to have the charges regarded as «disclauder», and therefore as no grounds for a trial against him.

15 «On Bishop Boothe», in WRIGHT, T., ed., Political Poems and Songs Relating to English History, Rolls Series, London, 1859-61, ii, p. 228. Poem mentioned in MCCULLOCH and JONES, «Lancastrian Politics», p. 120. Suffolk's patronage of Booth resulted in his appointment in 1445 as chancellor to the new queen Margaret of Anjou, and in 1447 as bishop of Coventry and Lichfield. Though he was marked by his association with Suffolk, after 1450 Queen Margaret and the duke of Somerset continued to show him favour, and Booth was translated to the archbishopric of York in 1452. He survived the shifting political winds well enough to join the archbishop of Canterbury for the crowning of Edward IV in Westminster Abbey. When he died in 1464, he left 
Before considering the Suffolk bills themselves, I should offer a brief definition of sorts - what is a bill? The word can refer to many things in this period, but often carries with it the association of a formal complaint, legal charge, or petition ${ }^{16}$. In this particular case however, John Stanes was referring to bills in rhyme when he stated that bills had destroyed the duke. It should be noted that these bills in rhyme, also referred to by scholars as libels, squibs, satirical verses, political poems, were handwritten texts typically on single sheets explicitly written for public display on windows and doors. Although we are some decades prior to William Caxton's introduction of the printing press to England in 1476, nevertheless such scribal bills were intended for broad circulation. This is what makes them dangerous. The act of posting such bills in rhyme intended to catch the eyes and ears of passersby can be traced back to the early part of the fourteenth century, but becomes widespread in the mid-fifteenth century, just about the time of Suffolk's murder ${ }^{17}$.

Presumably of course many of these bills have been lost - this is often what happens to libellous verses placed on windows and doors - but some were in fact copied down by a partisan preservationist ${ }^{18}$. One of the rolls in the Cotton collection in the British Library (Cotton Roll ii. 23), contains many contemporary verses against Suffolk, all well-known to scholars because they were edited by Thomas Wright in the nineteenth century as part of his Political Poems and Songs. C. L. Kingsford supposed this roll to have been compiled about 1452 by a citizen of London who supported the Yorkist cause, as it also contains a copy of the articles of impeachment against Suffolk from the rolls of parliament, a copy of one of the petitions which circulated during Jack Cade's rebellion, a copy of the duke of York's bill to the

behind the reputation of a talented administrator. REEVES, A. C., «Booth, William (d. 1464)», Oxford Dictionary of National Biography, Oxford, 2004.

16 SCASE, W., « $\langle$ Strange and Wonderful Bills $\rangle$ : Bill-Casting and Political Discourse in Late Medieval England», New Medieval Literatures ii (1998), p. 237.

17 SCATTERGOOD, V. J., Politics and Poetry in the Fifteenth Century, London, 1971, p. 25; GRANSDEN, A., Historical Writing in England, London, 1982, p. 238; SCASE, « Strange and Wonderful Bills»», p. 40. On bill posting in the mid-fifteenth century, see MCCULLOUGH and JONES, «Lancastrian Politics», p.117, where they cite WRIGHT, Political Poems and Songs, ii, pp. liv-lv, who makes much the same observation; see also ROSS, C. D., «Rumour, Propaganda and Popular Opinion During the Wars of the Roses», in GRIFFITHS, R. A., ed., Patronage, the Crown, and the Provinces, Gloucester, 1981, p. 22.

18 For a brief discussion of verse bills which have been lost, see SCATTERGOOD, Politics and Poetry, pp. 30-32; SCASE, «Strange and Wonderful Bills»», p. 228. GRUMMITT, D., «Deconstructing Cade's Rebellion: Discourse and Politics in the Mid Fifteenth Century», in CLARK, L., ed., Fifteenth Century VI, Woodbridge, 2006, p. 110, 115, discusses the significance of the preservation and transmission of such verse bills. 
king, and several prophesies ${ }^{19}$. Possibly the complier included the verse bills as evidence of the popular feeling against Suffolk or as artefacts of political discontent (even if, as I suggest below, the bills themselves were crafted to foment or appropriate the popular voice $)^{20}$. The practice of collecting such bits of documentary evidence then in circulation was becoming more widespread around the middle of the fifteenth century, perhaps with an eye toward a significance to history as well as sating the current desire for news, for the Paston letters contain many ancillary documents alongside the family correspondence, as too does the archive of Sir John Fastolf ${ }^{21}$.

Thomas Wright classified those verses pertaining to Suffolk as «political songs», and though there is no mention of a specific tune which accompanied them, we might imagine the mocking and accusatory words being sung aloud to some popular melody in taverns, marketplaces, and other public places ${ }^{22}$. The ballad form is certainly important. Ballads are easily remembered and recited or sung, and so quickly passed from one ear to the next $\mathrm{t}^{23}$. However once a ballad is displayed in the form of a bill, it also serves as a written record of what is being said (or sung) about someone of stature by the common people, or more specifically by the commonality of the realm. Such bills contain what appear to be popular allegations and complaints against Suffolk then in current circulation, thereby lending rumour, or «odious and horrible langage», something of the legitimacy of a legal charge brought forth by the community of the realm, much like the authority claimed by the crew of the Nicholas of the Tower to execute the duke after subjecting him to a mock trial.

19 KINGSFORD, C. L., English Historical Literature in the Fifteenth Century, Oxford, 1913, pp. 355-68.

20 KINGSFORD, English Historical Literature, p. 242; see also ROBBINS, R. H., Historical Poems of the XIVth and XVth Centuries, New York, 1959, p. xxix n. 31, and xxx where he suggests the items contained in the roll were written about 1450 or 1451, with May 1452 the latest date possible.

21 LIM, H. K., «Take Writing: News, Information, and Documentary Culture in Late Medieval England», unpublished PhD dissertation, 2006, p. 60 and n. 63 which cites RICHMOND, C., «Hand and Mouth: Information Gathering and Use in England in the Later Middle Ages», Journal of Historical Sociology 1 (1988), pp. 244-45 on Fastolf and his collection of documents.

22 Political Poems and Songs, ii, p. lv.

23 The Princeton Encyclopedia of Poetry and Poetics, Princeton, 2012, defines a ballad broadside as «a journalistic song printed on a single piece of paper (a Broadside) often chronicling a newsworthy event». It is «a product of urban journalism». See also introduction to Ballads and Broadsides in Britain, 1500-1800, eds. FUMERTON P. and GUERRINI, A., Farnham, 2010, pp. 1-13; FOX, A., Oral and Literate Culture in England, 1500-1700, Oxford, 2000, p. 301; FRIEDMAN, A. B., «The Late Medieval Ballads and the Origins of Broadside Balladry», Medium Aevum 27 (1958), pp. 95-110. 
In considering the credibility of the charges and accusations contained in such bills, we might think about the reception to broadside ballads in the early modern period, and the comedic character of the shepherdess Mopsa in Shakespeare's The Winters' Tale. Upon perusing the printed ballads for sale by the peddler and trickster Autolycus, Mopsa remarks «I love a ballet in print, a-life, for then we are sure they are true» (IV, 4, 2145). Though of course Mopsa is not quite so naive as this, for a moment later she pauses to wonder, «Is it true, think you» ${ }^{24}$ ? The political verse bills of the mid-fifteenth century had well anticipated Mopsa's moment of doubt - the phrase «this bille is trew» appears in a bill against Suffolk included by Wright under the title «A Warning to King Henry» ${ }^{25}$. This truth claim echoes the legal formula iste billa est vera, which endorsed indictments (an accusation made formal in writing) that had been pronounced by a jury to be true. Such indictments were then used to initiate criminal trials ${ }^{26}$. The verse bill adopts a rhetorical strategy which occupies the interstitial spaces between popular oral traditions of ballads and the erudite world of legal instruments.

Just as Shakespeare's Mopsa, we must not be too naïve in our reading of the accusations made against the duke in the bills, and I would not go so far as to suggest that the Suffolk bills contain an authentic common voice or reflect accurately the public outcry against the duke. Rather I think they were meant to foment the public outcry and quite possibly, depending on the timing of their dissemination, influence the impeachment proceedings against Suffolk. This is because Stanes' account of his participation in the plot to undo Lord Cromwell by bill posting suggests the strong likelihood that a small group of individuals similarly were behind the Suffolk bills, as will be discussed below. If perhaps two or three scandalmongers had gathered in an alehouse to scribble out the lines

We trow the kyng be to leere,

To seele bothe meene and lond in feere;

Hit is agayne resoun.

But yef the commyns of Englonde

Helpe the kynge in his fonde,

Suffolk wolle bere the crowne $e^{27}$

${ }^{24}$ As discussed in an unpublished talk by DOLAN, F. E., «Mopsa's Method: Truth Claims, Ballads, and Print», given at the Huntington Library, San Marino, California on 4 April 2014. See also DOLAN, F. E., True Relations: Reading, Literature, and Evidence in Seventeenth-Century England, Philadelphia, 2013.

25 Political Poems and Songs, ii, p. 231.

26 SCASE, Literature and Complaint, pp. 44-45, 128 and n. 148.

27 The last lines mean that if the commons do not help the king, Suffolk will wear the crown. From the abovementioned «A Warning to King Henry», Political Poems and Songs, ii, p. 230. 
or if perhaps one able verse-writer alone had been employed to compose the bills in rhyme, such an author deliberately appropriated the common voice to achieve his ends. Of course the act of appropriating the common voice is no less significant than the representation of the authentic common voice itself, for such bills in rhyme demonstrate the continual interplay between the written and the oral form, reminding us that oral communicative practices might make use of scribal and literate culture only to further oral communication, particularly if vindictive motives are at play ${ }^{28}$. In other words, writing was used in this instance to further rumour's reach ${ }^{29}$.

To return now to the subject of what the bills against Suffolk said, or perhaps how they said it. As they were intended for public display, these bills in rhyme often employed a symbolic or allegorical language of sorts — for example in «On the Arrest of the Duke of Suffolk», Suffolk is referred to by the nickname Jack Napes, which was the popular term for a monkey ${ }^{30}$. This was because Suffolk's badge was a clog and chain of the sort put on tame monkeys ${ }^{31}$. In "On the Popular Discontent at the Disasters in France», the nobles are similarly identified by their badges, or heraldic signs, all of which were as well-known as their names - thus the duke of Bedford is the root of a tree, the duke of Gloucester is the swan, the duke of Exeter is the fiery cresset, the duke of Somerset is the portcullis, and so on ${ }^{32}$. Why would the author use badges in the place of names?

28 FOX, Oral and Literate Culture, p. 301. See also SCASE, « «Strange and Wonderful Bills », p. 246; Galloway «The Common Voice in Theory and Practice in Late Fourteenth Century England», in KAEUPER, R. W., ed., Law, Governance, and Justice: New Views on Medieval Constitutionalism, Leiden, 2013, pp. 243-86; WATTS, J., «Public or Plebs: The Changing meaning of «The Commons`, 1381-1549», in PRICE, H. and WATTS, J., eds., Power and Identity in the Middle Ages: Essays in Memory of Rees Davis, Oxford, 2007, pp. 242-60.

29 See WALKER, S., «Rumour, Sedition and Popular Protest in the Reign of Henry IV», Past and Present 166 (2000), pp. 31-65. In one sense, the relationship between orality and print in these bills suggests a balance between time and space of the sort discussed by communications theorist Harold Innes in his 1950 work, Empire and Communication. However in another sense the present-mindedness of the subject matter in the verse bills may signal an early instance of the shift to an emphasis on space and power in media.

30 Political Poems and Songs, ii, pp. 224-25. I have elected to refer to the verse bills by the titles given in Wright's edition.

31 The word jackanapes lingers in our modern English language, and though it first appears in various forms in these Suffolk bills, it is believed that Jack Napes was already in the mid-fifteenth century a proper name for a tame monkey. See «jackanapes, n.» OED Online. Oxford University Press, March 2014.

32 Political Poems and Songs, ii, pp. 221-23. Detailed explanatory notes regarding the badges associated with each noble accompany the version of the verse which appears in COLLIER, J. P., esq., ed., Trevelyan Papers prior to A. D. 1558, London, Camden Society, 1857, p. 65. 
The badge or heraldic sign was both a principal aspect of the public construction of a nobleman's identity and a representation of the material basis of a noble's power. Therefore the verse bill's use of such widely recognizable cognomens for the nobles lends an air of political authority to the narrative, encouraging readers (or singers) to view such texts as authoritative participants in the political discourse of the moment ${ }^{33}$. Brigitte Miriam Bedoz-Rezak has theorized the relationship between the use of seals by elites and the construction of social identity in the twelfth and thirteenth centuries, and we might think of badges in the later centuries in similar terms, important because the heraldic badge came to represent a nobleman's public identity, important because a badge could be distributed, reproducing or branding the noble's identity on a band of followers ${ }^{34}$. Inevitably the proliferation of such signs was very much an issue in the later middle ages, particularly during the reign of Richard II when complaints against the widespread distribution of badges to retainers multiplied in parliament ${ }^{35}$. By 1450 then, in certain contexts, heraldic badges or signs were associated with a longstanding tradition of political discourse and complaint.

The Suffolk bills are not the earliest poetical texts to refer to the nobility by their badges - rather this seems to be a phenomenon associated with the deposition of Richard II, or more precisely with the project of Lancastrian legitimation $^{36}$. Three poems in particular, Richard the Redeless, John Gower's Cronica tripertita, and the anonymous poem published by Thomas Wright under the title «On King Richard's Ministers», all make use of heraldic allegory, referring to Thomas of Woodstock, duke of Gloucester, Thomas Beauchamp,

33 BARR, H., Socioliterary Practice in Late Medieval England, Oxford, 2003, pp. 71-73; AILES, A., "Heraldry in Medieval England: Symbols of Politics and Propaganda», in COSS, P. and KEEN, M., eds., Heraldry, Pageantry and Social Display in Medieval England, Woodbridge, Suffolk, 2002, p. 104.

34 BEDOS-REZAK, B. M., «Medieval Identity: A Sign and a Concept», American Historical Review, 105 (2000), pp. 1489-1533. Consider also CLANCHY, M., England and its Rulers, 1066-1272, 2nd ed., Oxford, 1998, p. 135 on the use of the seal by Henry II; WATTS, J., «Looking for the State in Later Medieval England», in COSS, P. and KEEN, M., eds., Heraldry, Pageantry and Social Display in Medieval England, Suffolk, 2002, pp. 265-66. On the power implied by such cognomens, see STEINER, E., «Naming and Allegory in Late Medieval England», The Journal of English and Germanic Philology 106 (2007), pp. 272-75.

35 TUCK, A., «The Cambridge Parliament, 1388», English Historical Review 74 (1969), pp. 225-43; SAUL, N., «The Commons and the Abolition of Badges», Parliamentary History (1990), pp. 301-15; PATTERSON, L., Chaucer and the Subject of History, Madison, 1991, pp. 192-93; STROHM, P., Hochon's Arrow, Princeton, 1992, pp. 179-85; OlIVER, C., Parliament and Political Pamphleteering in Fourteenth-Century England, Woodbridge, 2010, pp. 132-36.

36 BARR, H., Socioliterary Practice in Late Medieval England, Oxford, 2003, p. 79. 
earl of Warwick, and Richard Fitzalan, earl of Arundel by their respective badges of the Swan, Bear, and the Horse ${ }^{37}$. All three poems belong to what Frank Grady has named «the generation of 1399», and scholars continue to debate whether and why the moment after the deposition of Richard II required such circumspection or the use of coded language, particularly as Gower states that he wishes to cloak the identity of the nobles «disguisedly, in hidden form ${ }^{38}$. Yet Gower has already made the code transparent in the explicit to the Vox clamantis, where he states, «There were then three nobles of the realm who were especially disturbed by all this, namely, Thomas Duke of Gloucester, who is commonly called the Swan; Richard Earl of Arundel, who is called the Horse; and Thomas Earl of Warwick, whose name is the Bear» ${ }^{39}$. Why then do the poems of the generation of 1399 engage in such an obvious game of subterfuge? Do they do so to avoid directly naming names, thereby avoiding the danger that comes with explicit political writing or skirting contemporary notions of defamation ${ }^{40}$ ? The answer to this question in regard to the poems associated with Richard II's deposition remains contested ${ }^{41}$. However I would argue that in the case of the Suffolk

37 «On King Richard's Ministers» is found in Political Poems and Songs, i, pp. 363-66; the same poem is published by DEAN, J. M. as «There is a Busch That is Forgrowe», in Medieval English Political Writings, Middle English Texts, Kalamazoo, 1996, pp. 150-52.

38 GRADY, F, "The Generation of 1399», in STEINER, E. and BARRINGTON, C., eds., The Letter of the Law: Legal Practice and Literary Production in Medieval England, Ithaca, New York, 2002, pp. 202-29. English translation from The Major Works of John Gower, trans. STOCKTON, E., Seattle, Washington, 1962, p. 291. In considering Gower's use of allegory, scholars often refer to The Prophecy of John of Bridlington which enumerates the many ways an author might practice concealment of his subject matter. One of these is to refer to a person by heraldic allegory, precisely as Gower does. The Prophecy is in Political Poems and Songs, i, pp. 123-215, with the relevant section at pp. 126-27.

39 From explicit to Vox clamantis, in The Major Latin Works of John Gower, p. 288. Gower repeatedly offers explanation for the encoding of the names of nobles in Cronica tripertita as well - «Note the names of the three aforesaid nobles, in a figure of speech: the Earl Marshall; the most valiant Earl of Derby; the earl of Northumberland, whose Badge was a crescent moon», The Major Latin Works of John Gower, p. 291. See also p. 300, where Gower again explains that the Duke of Gloucester is called the «Swan».

40 On political defamation, see HANRAHAN, M., «Defamation as Political Contest during the Reign of Richard II», Medium Aevum 72 (2003), pp. 259-72.

${ }^{41}$ See most recently CARLSON, D. R., John Gower, Poetry and Propaganda in FourteenthCentury England, Woodbridge, 2012, pp. 126-35, who argues at length that such allegories were non-popular, deliberately obscure. For a contrasting perspective, see BATKIE, S. L., «Radical Conservation and the Eco-logy of Late-Medieval Political Complaint» in SCHIFF, R. and TAYLOR, J., eds., The Politics of Ecology: Land, Life, and Law in Medieval Britain, Columbus, forthcoming. Batkie presents the view that such allegories were easily understood — «allegory makes political readable». 
bills of the mid-fifteenth century, composed as they were to be posted in public places, these bills only strive to appear circumspect because it was widely understood that this is precisely what political verse should do circumspection gives the bills a prophetic quality, one long associated with political writing ${ }^{42}$. If nothing else, the poets belonging to the generation of 1399 had succeeded in establishing a discourse of circumspection which conveyed an intimate political knowledge of the subject, and as I have suggested above, the author (or authors) of the Suffolk bills likely deployed this discourse of circumspection because it made the accusations against Suffolk and his associates seem all the more credible. We must understand that the heraldic allegories contained in the Suffolk bills are no more than thinly veiled allusions, and there can be no doubt that they were intended to be widely understood by the public - to be transparent rather than opaque - perhaps because their origin was popular, or so Gower himself would have us believe ${ }^{43}$. At the end of part two of the Chronica tripertita, Gower cites a «song which malicious men composed»: «The Swan does not keep its wings forever, nor the Horse its hide; now the Swan is without wings, the Horse is flayed. The Bear, whom biting chains torment, does not bite». This spiteful bit of verse was recited by «the voice of the fatuous mob», which may well have had a way with words ${ }^{44}$.

Now to the Suffolk bills themselves. One of earliest of these verses against the duke seems to date from late 1449, presumably after the loss of Rouen, and perhaps sets the expectations for the nature of the public attack on Suffolk which is to come in that it focuses on the English defeat in France. The first lines of this verse lament the passing of the older generation who had successfully commanded or supported the war in France, men such as Bedford, Gloucester, and Exeter, all here referred to by their badges or signs - Gloucester is «the Swan is gone» ${ }^{45}$. There is plenty of blame to go around - various members of Suffolk's court circle are accused of having misled

42 BARR, Socioliterary Practice, pp. 72-73.

43 As WRIGHT, Political Poems and Songs, ii, p. lv, observes of the Suffolk bills, «In these political troubles it was customary to speak of the leaders by their signs or badges, which were as well known as their names or titles, and which had the advantage of being more comprehensive, as they were worn by their followers, who were thus recognized at a glance». See also NICHOLSON, R., "The Poetry of Partisanship in Mid-Fifteenth-Century England», in REEVES, A. C., Personalities and Perspectives of Fifteenth-Century England, Tempe, 2012, p.102.

44 The Major Latin works of John Gower, p. 309. CARLSON, John Gower, Poetry and Propaganda, p. 134, regards this song as blatant fiction on the part of Gower.

45 Political Poems and Songs, ii, pp. 221-23. Wright gives the title as «On the Popular Discontent at the Disaster in France» (written about 1449). 
or blinded the king. But Suffolk himself gets off rather lightly — the «Ape Clogge» as he is named is motivated by an envy of the war heroes, and he is blamed for withdrawing support from «our good dog John Talbot», one of England's most able commanders.

Another verse bill written just after Suffolk's arrest on the 28 January 1450 links John Talbot's (and so Normandy's) fate to Suffolk's policies - a line reads «But he that tiede Talbot oure doge, evylle mot he fare» ${ }^{4}$ ! Here Suffolk appears as a Fox driven into a hole, or alternatively as «the Fox is in the Towre» - Suffolk was in fact imprisoned in the Tower of London, probably for his own safety as much as anything. Now this verse bill is more explicit in the nature of its attack than the one which circulated a few months prior and so more interesting; here a violent remedy is sought, specifically the duke's hanging at Tyburn. The bill warns against (if not predicts) Suffolk's escape from punishment, stating «ffor and he crepe out, he will yow alle undo». Furthermore the bill voices the concern that the duke's friends still lurk at court -

Many mo ther bene, and we knowde hem knowe;

But wonne most begynne the daunce, and all come

arowe.

As Isabel Harvey has observed, it is easy for us to imagine «that some men and women may have been singing or dancing to these refrains ${ }^{47}$.

The other contemporary verse bills from about the time of Suffolk's arrest and impeachment echo similar fears and warnings regarding the duke's influence and circle of friends at court, and further reiterate in one form or another the charge that Suffolk was responsible for the loss of Normandy. The bill mentioned previously which targeted the Suffolk favourite Bishop Booth plays on the duke's name at one point, praying that God save the king from «Southefolkes» (Suffolk), and from his «foois alle» ${ }^{48}$. The verse known as «A Warning to King Henry» contains the memorable line «Suffolk Normandy hath swolde», a rumour that had been also reported in parliament. It accuses Suffolk of wanting the crown for himself, and cautions the king against letting Suffolk and his circle off the hook -

Let no lenger they traitours go loos;

They will never be trewe.

The traytours are sworne alle togedere

To holde fast as they were brether ${ }^{49}$.

46 «On the Arrest of the Duke of Suffolk». Political Poems and Songs, ii, pp. 224-25.

47 HARVEY, I. M. W., Jack Cade's Rebellion of 1450, Oxford, 1991, p. 77.

48 Political Poems and Songs, ii, pp. 225-29.

49 Political Poems and Songs, ii, pp. 229-31. 
Thus Suffolk and his supporters are not «trewe» men. «Trewe»ness of course has a longstanding association with political protest, from the «trew communes» of 1381 to the «trewe Comyns» which appears in the bills of complaint associated with Jack Cade's rebellion in 1450. Truth was constructed as the opposite of treason in both law and common parlance, just as it is in the lines cited above, where trewe is contrasted with the traytours sworne all together. Should these lines pass from lips to ears in public places as must have been intended, the commonality of the realm enacts its «trewe»ness by exposing Suffolk and his cronies as traitors to the realm ${ }^{50}$.

Another and more ominous verse bill in this same collection puts Suffolk's supporters on notice - they must abandon him «within this monthes thre», or suffer the consequences ${ }^{51}$. Thus the accusations against the duke found in these bills are typically accompanied by prescriptions, just as John Stanes had suggested - the fear that Suffolk would escape punishment came with the threat of «or else» ${ }^{52}$. These bills promised the duke and his circle's destruction should parliament fail.

A particularly long verse bill celebrating Suffolk's eventual fate is preserved in a remarkable three manuscript versions ${ }^{53}$. The poem is a post mortem of sorts, written after the duke's murder, and often referred to by its cheeky first line, «In the monethe of May when gresse groweth grene». Of course May 1450 was not a month of verdant renewal so much as popular revolt, and Wendy Scase has suggested that this jubilant verse celebration of Suffolk's murder which parodies the Office of the Dead might have circulated with one of the Cade petitions. Both Scase and V.J. Scattergood have observed that the long list of Suffolk adherents contained in one version of the poem (MS Lambeth 306, the longest version) is remarkably similar to the names

50 GREEN, R. F., A Crisis of Truth: Literature and Law in Ricardian England, Philadelphia, 1999, pp. 206-47. «Trewe comyns» appears particularly in the version of the petition from 1450 contained in Cotton Roll II 23.

51 «Verses against the Duke of Suffolk», Political Poems and Songs, ii, p. 231.

52 SCASE, «Strange and Wonderful Bills»», p. 233, observes this to be typical of such bills, such as William Paston's encounter with a bill in 1424 .

53 In Dublin, Trinity College, MS 516, f. 116 and in British Library MS Cotton Vespasian. B. xvi, ff. 1. These versions were written after 3 May but before 29 June 1450 . The Cotton Vespasian version is in Political Poems and Songs, ii, pp. 232-35 and in Historical Poems of the XIVth and XVth Centuries, pp. 187-89. The quotation above is from Political Poems and Songs. The third and longest version is Lambeth MS 306, in John Stow's hand. Lambeth MS 306 was probably written months later, perhaps in November 1450 prior to the introduction of the commons petition in parliament. On the dating and manuscript history see SCASE, Literature and Complaint, pp. 129-31, HARVEY, Jack Cade's Rebellion of 1450, p. 79 n. 18. 
found in a petition by the parliamentary commons from November 1450 that demanded the removal of this circle from the king's presence - neither scholar quite comes out and says this, but I think the implication is that the verse bill celebrating Suffolk's demise was circulated in order to lay the groundwork for the common petition requesting the removal of Suffolk's supporters ${ }^{54}$.

Lastly, the following jubilant three little lines of rhyme:

But Suthfolke, Salesbery and say

Be don to deathe by May

England may synge well away

were observed by the Londoner John Piggot to have been set on the gates of St. Paul's ${ }^{55}$. Both the bishop of Salisbury and Lord Saye were close associates of Suffolk, and similarly met a violent end in 1450. The bishop was murdered by his flock on 29 June of that year, and Saye was dragged out of the Tower, a trial was staged, and he was beheaded by Cade's rebels on 4 July. Though we cannot be sure just when John Piggot spied this verse - before or after Suffolk's murder - nevertheless it is tempting to imagine such bills as a call to vigilantism.

As mentioned, all of these verse bills are well trodden ground to scholars of the period, and historians such as McCulloch and Jones have tended to regard them as evidence that by 1450 , the tide of public opinion had turned against Suffolk, and furthermore, that public opinion did matter ${ }^{56}$. And of course it did.

However I would argue that these verse bills tell us something about why slander in particular was such an effective weapon in this period, and why the so-called public of the mid-fifteenth century was ready to read accusations such as «Suffolk Normandy hath swolde» as credible or to be incited by such texts. Taking a slightly different tack, Wendy Scase has examined the Suffolk bills as part of her larger work on the history of clamour, the complaint culture shaped by what she describes as «neglected, despised, marginal texts $»^{57}$. Building on her work, I find it helpful to

54 SCASE, Literature and Complaint, pp. 128-31; SCATTERGOOD, Politics and Poetry in the Fifteenth Century, p.168.

55 KINGSFORD, English Historical Literature, p. 370. Dating is discussed by SCASE, Literature and Complaint, p. 125 n. 145.

56 MCCULLOCH and JONES, «Lancastrian Politics», pp. 95-138.

57 SCASE, Literature and Complaint, p. 2; see also WICKER, H., «The Politics of Vernacular Speech: Cases of Treasonable Language, c. 1440-1453», in SALTER, E. and WICKER, H., eds., Vernacularity in England and Wales, c. 1300-1500, Turnhout, Belgium, 2011, pp. 171-197. 
regard such verse bills as part of a proto-tabloid culture that emerges with England's losses in France in this period ${ }^{58}$. This was a particularly important moment because public discussion of England's foreign policy had been deliberately stifled since the mid-1440s. For example, the historian John Watts has convincingly framed Good Duke Humphrey's - the duke of Gloucester's - demise in 1447 as a chilling indication of how far the leading magnates of the realm would go to avoid «a major public debate about foreign policy and how it had been made» ${ }^{59}$. Secrecy had taken hold with the difficult if not botched negotiations for the surrender of Maine to the French crown which took place in the first part 1447. In May, Suffolk, who had taken a leading role in the negotiations, came before the lords in council to defend himself against slanderous rumours that he had provided false counsel to the crown - a declaration was made that all such calumniators would suffer appropriate punishment ${ }^{60}$. It seemed that the calumniators would have the last say, for as demonstrated by the aforementioned bills, such rumours about Suffolk's betrayal of the English cause in France persisted unchecked despite attempts by the crown to bring to a halt the billsticking ${ }^{61}$. Thus I would suggest that the prototabloid culture which comes to the fore in 1450 reveals something about popular expectations for and disappointments in the political discourse of the day. It says something, as does Jack Cade's rebellion which followed on the heels of Suffolk's murder, about the unmet desire of the community of the realm for openness during the closing years of the war with France, as without guidance from the crown, the community of the realm struggled to makes sense of the mounting losses.

The trial against Suffolk was made the more dramatic by the duke's determination to clear his name ${ }^{62}$. The signs of trouble were clearly evident when parliament reconvened on 22 January 1450, shortly after the murder

58 These bills have much in common with «White-Letter» ballads of the seventeenth century - political satires written anonymously and circulated on the streets of London for public consumption which had been commissioned by particular interest groups to make a case. See Angela MCSHANE, «Ballads and Broadsides», in RAYMOND, J., ed., The Oxford History of Popular Print Culture. Volume 1: Cheap Print in Britain and Ireland to 1660, Oxford, 2011, pp. 357-58.

59 WATTS, Henry VI and the Politics of Kingship, p. 231.

60 Dated 18 June 1447 in T. RHYMER, ed., Foedera, Conventiones et Litterae, London, 1709 , xi, p. 172.

61 HARVEY, Jack Cade's Rebellion of 1450, p. 31, 70.

62 For much of the narrative of Suffolk's trial which follows, see GRIFFITHS, The Reign of King Henry VI, pp. 676-82; PROME, parliament of Henry VI, 1449 November, «Introduction». 
of Adam Moleyns by a mob of angry sailors and soldiers at Portsmouth ${ }^{63}$. Suffolk asked to make a formal statement before the lords, hoping to head off the inevitable attack against him, and he affirmed that he was willing to answer his accusers directly. On 28 January, the commons made the specific charge that Suffolk intended to turn Wallingford castle over to the French enemy, and this was enough to justify sending Suffolk to the Tower on 29 January. A little over a week later, the bill of impeachment was presented by the speaker of the commons, William Tresham. The king then suspended the impeachment proceedings, thereby causing a lengthy and strategic delay of six weeks during which Suffolk was confined to the Tower. Then on 13-14 March, having had adequate time to prepare, Suffolk finally made his public answer to the charges. His defence was both spirited and convincing, for he insisted that the official record would show he had done nothing treasonous, something which he had been careful to document all along.

There are several texts associated with Suffolk's trial. There are at least two official or semi-official texts associated with Suffolk's impeachment - the commons' charges against him seem to have circulated in several copies, one of which was collected by the Pastons; and to Suffolk's defence someone crafted a detailed and vehement reply which provided additional information regarding the duke's culpability, particularly in regard to the loss of Normandy - one of the more salacious details the author or authors thought to include was that during his time as a soldier in France, Suffolk had spent a torrid night with a nun by which he conceived an illegitimate daughter ${ }^{64}$. This too is a text which bridged the world of legal instruments and the world of salacious and titillating rumours regarding public figures, much as today's tabloids do.

There is another text perhaps less well-known. It is a text specifically associated with Suffolk's impeachment by the parliamentary commons, and it suggests why these verse bills were so effective - because they presented a

63 Moleyns was keeper of the privy seal and bishop of Chichester, and was widely regarded as a close associate of Suffolk's. He had gone to Portsmouth to pay back wages to the soldiers awaiting deployment to Normandy. On this and the short-lived rising which followed Moleyns' murder, see HARVEY, Jack Cade's Rebellion of 1450, pp. 63-64.

64 The manuscript copies of the commons' charges against Suffolk as well as the second text which contained further and malicious accusations against the duke are subject to a detailed discussion by SCASE, Literature and Complaint, pp. 122-24. Following Scase's footnotes, on the copy of the commons' charges in the Paston archives, see The Paston Letters 1422-1509, i, pp. 99-105. The second text can be found in Great Britain, Royal Commission on Historical Manuscripts, Third Report of the Royal Commission on Historical Manuscripts, London, 1872, pp. 279-80, reprinted from the manuscript Oxford, Bodleian Library, MS Eng. Hist. B. 119. 
challenge to the practice of concealment by the crown. As I mentioned above, Suffolk's grandfather, Michael de la Pole, chancellor of England under Richard II, had been similarly impeached in 1386, in the Wonderful Parliament, and subsequently charged with treason in 1388 along with a group of favourites, and convicted in absentia by the Merciless Parliament. A contemporary account of the so-called Merciless Parliament of 1388, written by Thomas Favent, begins with a brief account of Michael de la Pole's impeachment in $1386^{65}$. Favent's Historia mirabilis parliamenti is familiar to many because it is an important source for Richard II's reign; but there also exists a later copy of Favent's narrative; a copy was made in the mid-fifteenth century - mostly likely from the evidence of the manuscript hand it was copied in 1450 in anticipation of grandson Suffolk's impeachment. There is no indication that this later copy circulated - the manuscript, which is in a private collection in New York, is too well-preserved, and the manuscript decorations such as the pen-flourished initials and paragraph marks were never completed. Nevertheless someone went to the trouble of making the copy, perhaps on the off chance it would come in handy in 1450. The Wonderful and Merciless parliaments of Richard II's reign had not been forgotten ${ }^{66}$.

I would propose that the copying of Thomas Favent's account of the Wonderful and Merciless parliaments offers a clue about the expectations surrounding grandson Suffolk's impeachment in 1450. The first expectation was that the crown would cooperate with the commons in allowing the impeachment proceedings to go forward, just as they had in 1386. This is perhaps why copies of the charges against Suffolk had been put into circulation, to insure broad support for parliament of the sort enjoyed in 1386. Instead, on 17 March the king called a gathering of the lords in his chamber at Westminster palace. There, and not in the parliament chamber, Henry VI formally dismissed the first set of charges against Suffolk, those to do with England's losses in France; in regard to the second set of charges, those to do with corruption and misconduct, the king placed the duke under the crown's own «rule and governaunce ${ }^{67}$. The impeachment was quashed.

65 The full title of Favent's narrative is Historia siue narracio de modo et forma mirabilis parliamenti apud Westmonasterium anno domini millesimo CCCLXXVJ, regni vero Regis Ricardi secundi post conquestum anno decimo.

66 The 1450 manuscript of the Historia mirabilis parliamenti is discussed in OLIVER, C., «New Light on the Life and Manuscripts of a Political Pamphleteer: Thomas Fovent», Historical Research 83 (2010), pp. 60-8 and in OLIVER, Parliament and Political Pamphleteering, pp. 188-91. For the discussion of Favent's account of the Merciless Parliament which follows, see Parliament and Political Pamphleteering, pp. 84-116, 150. 
A second expectation regarding Suffolk's impeachment had to do with another aspect of Favent's Historia mirabilis parliamenti. One of the more compelling aspects of Favent's text is his detailed description of the Merciless Parliament of 1388, and early in his account he reports that when the trials against Richard's favourites began in the White Chamber at Westminster on 3 February, «there was a single mass of men filling the hall even to the corners ${ }^{68}$. In 1388 , according to Favent, crowds occupied parliament. Parliament thus became a public forum for airing corruption.

But this was not so in 1450 . In 1450 , the public was very much outside parliament, in the form of rumours circulating about. The proceedings against the duke took place either in the parliament chamber or in the palace, but Suffolk skilfully managed to transform such spaces into a forum for his selfdefence, forcefully refuting the commons' charges, and citing the alarming rumours and accusations flying around London and Westminster - the voices on the outside. Rumour, it had been argued by the lords in parliament near the beginning of the proceedings, should prove no basis for the duke's arrest $^{69}$. However Suffolk was placed under arrest anyway, his confinement in the Tower celebrated in one of the verses discussed above.

Of course the danger of voices left outside is that they are often difficult to locate. And therefore difficult to silence. Consider the perfectly obvious fact that the authors of verse bills don't attach their names to them though perhaps we could - Roger Virgoe reminds us that in 1453, Sir William Oldhall along with others in the service of the dukes of York and Norfolk were accused of conspiring in 1450 to put up around the town of Bury St. Edmunds bills in rhyme which the authorities believed had encouraged the murder of Suffolk and Jack Cade's rebellion ${ }^{70}$. Perhaps they were the very bills I have discussed. But if passersby knew that such bills were the work of identifiable partisans and lackeys, the rumours and accusations contained therein would be easy to discredit. Instead, anonymous, such verse bills are free to adopt the all powerful voice of the community of the realm, much as did the sailors of the Nicholas of the Tower. Why were they accepted as such?

I think in part, because the proto-tabloid culture of 1450 communicated a longing for transparency that the government was unwilling or unable to

68 Una vero hominum congluuies inibi fuerat aule usque in angulos. Favent, Historia mirabilis parliamenti, in Camden Miscellany, 14, ed. MCKISACK, M., London, 1926, p. 14.

69 PROME, parliament of Henry VI, 1449 November, item 16.

70 VIRGOE, «William Tailboys and Lord Cromwell», 475. SCASE « Strange and Wonderful Bills`», p. 232, doubts Oldhall's guilt. 
concede. Tabloids, of course, are about secrets being exposed. Reading the verse bills as proto-tabloids reminds us that such texts played important roles in demanding political transparency, in promoting government accountability, and in keeping an eye on government ministers who might otherwise indulge in corruption ${ }^{71}$.

The secret Suffolk himself threatened to expose to the public (and intimated by his speeches in parliament) was that he had not acted alone much of the nobility had lent their support to the truce negotiations with France, and Suffolk was not solely to blame for the fiasco in Normandy. So the duke was saved by the king, and sent into exile for five years. (Perhaps the greater secret was Henry VI's incapacity to rule, clearly apparent to those at the centre.) The night before he set out for the continent, Suffolk, who was married to Alice Chaucer, granddaughter of the poet, wrote to their seven-year-old son in loving terms - this letter too is preserved in the Paston letters. He instructed his son John «to be trewe liege man in hert, in wille, in thought, in dede, unto the Kyng...to whom bothe ye and I been so moche bounde to...» and «to love, to worshepe youre lady and moder, and also that ye obey alwey hyr commaundements, and to beleve hyr councelles and advises in alle youre werks» ${ }^{72}$. Private correspondence, particularly to someone of Suffolk's station, was one of courtesy and intimacy, as too was the world of poetry in which he was also immersed through his friendship with Charles d'Orleans ${ }^{73}$. Thus how alien this world of public writing with its slanderous attacks must have seemed to him, one which seemed deliberately to parody the ballades and roundels of the aristocratic world. But isn't this is what tabloids do? They parody both elite and middlebrow forms of communication.

And how difficult too for the historian of this period to know what to make of it all, the image of the loving father, the image of the deeply corrupt minister. As the historian J. R. Lander once so aptly described the second half of the fifteenth century, «In reality the political history of the period is

$\overline{71}$ As observed in an unpublished talk given by PEACY, J., «Bills set up in the Streets: Politics on Posts in Early Modern London», Pacific Coast Conference of British Studies, Riverside, California, 8 March 2014.

72 The Paston Letters 1422-1509, i, pp. 121-22.

73 There is some debate regarding the authorship of those poems attributed to Suffolk himself in MS Fairfax 16 and elsewhere. See JANSEN, J. P. M., The "Suffolk» Poems: An edition of the Love Lyrics in Fairfax 16 attributed to William de la Pole, Ph.D. diss, University of Groningen, 1989, pp. 14-21. My thanks to Mary-Jo Arn for this reference. See also PEARSALL, D., «Literary Milieu and the Fairfax Sequence», in ARN, M., ed., Charles d'Orleans in England, 1415-1440,Woodbridge, 2000, pp. 153-56. 
a web of shreds and tatters, patched up from meagre chronicles and from a few collections of letters in which exaggerated gossip and wild rumours have been, all too often, confused with facts» ${ }^{74}$.

If we had the facts, they might well obscure something important about the political culture of this period. This is, as I have tried to argue here, that by the mid-fifteenth century, political discourse of the public kind hasn't just been tainted or corrupted by rumour and slander, it has become these things. Cade's rebellion, after all, was sparked by the rumour that Henry VI would exact retribution for Suffolk's death by turning the county of Kent into a wild forest ${ }^{75}$.

Rumour and slander were nothing new, of course. But some periods and some governments are more susceptible than others ${ }^{76} .1450$ ushered in just such a period, when proto-tabloids could be used to destroy one's political enemies. They were effective because they embodied public accountability in its crudest and most accessible form. Thus we might regard the inception of the Wars of the Roses as the work of hack writers who transformed scandal into verse, and verse into violence.

74 LANDER, J.R., Crown and Nobility: 1450-1509, Montreal, 1976, p. 94.

75 See opening of the bill of complaint contained in BL Cott. IV 50 which is printed in appendix to HARVEY, Jack Cade's Rebellion of 1450, p. 186.

76 DARNTON, R., The Devil in the Holy Water, or the Art of Slander from Louis XIV to Napoleon, Philadelphia, 2010, pp. 437-45. 